\title{
Spouses and Unrelated Friends of Probands as Controls for Stroke Genetics Studies
}

\author{
Bradford Burke Worralla,b Devin L. Brown ${ }^{a}$ Thomas G. Brott ${ }^{c}$ \\ Robert D. Brownd Scott L. Silliman ${ }^{\mathrm{e}}$ James F. Meschiac \\ Departments of a Neurology, University of Virginia, bHealth Evaluation Sciences, University of Virginia, \\ Charlottesville, Va., ' Neurology, Mayo Clinic Jacksonville, Jacksonville, Fla., dNeurology, Mayo Clinic Rochester, \\ Rochester, Minn., and eNeurology, Shands/University of Florida, Jacksonville, Fla., USA
}

\section{Key Words}

Ischemic stroke · Genetics · Case-control study · Design/methodology

\begin{abstract}
To plan a multisite, ischemic stroke genetic study, stroke patients were surveyed about the availability and characteristics of a convenience sample of spouse/friend controls. $65 \%$ of all stroke-affected probands reported a living spouse. A more detailed survey was conducted at the University of Virginia, Charlottesville, Va., USA: $51 \%$ of stroke patients reported a living, stroke-free spouse who would be willing to serve as a control, and $49 \%$ reported having a stroke-free friend who would be willing to serve as a control. Overall, $75 \%$ of stroke patients reported at least 1 individual willing to participate as a control. Cases without an identified control were more likely to be nonwhite $(48 \%)$ than were cases with a control $(13 \%$; $p=$ $0.00004)$. Cases were older than controls (67.3 vs. 59.2 years; $p=0.000002)$, and a greater proportion of cases than controls were male ( $57 \mathrm{vs.} 33 \% ; p=0.0002$ ). Without proper attention to matching, the use of a spouse/friend convenience sample would result in imbalances in basic demographic characteristics.
\end{abstract}

Copyright @ 2003 S. Karger AG, Basel

\section{KARGER}

(C) 2003 S. Karger AG, Basel

Fax +41613061234

E-Mail karger@karger.ch

www.karger.com
Accessible online at: www. karger.com/ned

\section{Introduction}

The study of the genetics of cerebrovascular disease poses a number of challenges for investigators. Few doubt a hereditary contribution to cerebrovascular risk, but the quantification of genetic factors remains elusive. Several large-scale epidemiological studies have demonstrated that family history is associated with increased risk of stroke; the strength and consistency of that relationship has been variable $[1,2]$. The association may be stronger than observed in these studies because of differential and nondifferential misclassification. Many studies relied upon unconfirmed recollections or diagnoses made in the era preceding the routine use of computed tomography (CT) in clinical practice. Similarly, many studies did not distinguish among ischemic stroke subtypes [3-5] and, in some cases, even between ischemic and hemorrhagic strokes $[2,6]$.

Stroke is a phenotypically heterogeneous disease of the elderly. Many of the usual tools available to study the genetic contribution to a disease have limited utility in the study of cerebrovascular disease. Few pedigrees have multiple living affected family members in multiple generations due to both the high mortality associated with stroke and the late age of onset. Although affected sibling-pair

\footnotetext{
James F. Meschia, MD

Department of Neurology, Mayo Clinic

4500 San Pablo Road

Jacksonville, FL 32224 (USA)

Tel. +1 904953 7228, Fax +1 904953 7233, E-Mail meschia.james@mayo.edu
} 
strategies remain promising [7], case-control genetic association studies will continue to dominate efforts to tease out the complex genetics of cerebrovascular disease [8]. The use of spousal controls is frequent in genetic studies [9-11] and may have specific advantages, including convenience and controlling for adult environmental exposures [12]. We found no published empirical data on the appropriateness of spousal controls in genetic cerebrovascular studies. We sought to assess the feasibility of an ischemic stroke genetics study using cases with incident stroke and controls drawn from spouses and unrelated friend controls.

\section{Methods}

\section{Multisite Survey}

Data were collected prospectively on potential cases of recent ischemic stroke at the following academic medical centers: Mayo Clinic, Jacksonville, Fla.; Mayo Clinic, Rochester, Minn.; Shands/ University Hospital, Jacksonville, Fla., and the University of Virginia Health System, Charlottesville, Va., USA. During the spring of 2001, all individuals admitted to the neurology services at these hospitals were screened. Cases were patients with a recent CT- or MRconfirmed ischemic stroke not associated with a surgical/interventional procedure, subarachnoid hemorrhage, biopsy-proven vasculitis, mechanical heart valve, endocarditis, or a monogenic disorder known to cause stroke. Cases had to be over 18 years of age and had to have the capacity to provide informed consent for a genetics study. Each case was asked the question whether he/she had a living spouse. All data were collected anonymously. The multisite survey had been approved by each local institutional review board.

\section{University of Virginia Survey}

The University of Virginia Health System includes a 600-bed hospital with over 450 stroke admissions annually that provides both primary and tertiary care to the town of Charlottesville, Va., USA, and a surrounding 7-county region. At the University of Virginia site, a neurologist investigator administered a structured questionnaire to characterize cases and controls in better detail. All individuals admitted to the University of Virginia neurology service with a diagnosis of stroke were approached. Subjects were presented with a hypothetical scenario in which they would be invited to participate in a nontherapeutic stroke genetics study. Investigators collected basic demographic information about the cases including age, race/ethnicity, and marital status. They also collected basic medical information regarding common vascular risk factors and stroke subtype. A neurologist with subspecialty expertise in cerebrovascular diseases subtyped the presenting stroke by the TOAST classification system using all available clinical and laboratory information [13]. Cases were asked about the availability of their spouse to serve as a control in a genetics study. They were also asked about the availability of unrelated, stroke-free friends to serve as controls. To be deemed available, spouses/friends needed to be living, free of a history of stroke, and willing to participate in the estimation of their respective case. Data on age and race/ethnicity were also collected for both spouses and friend controls.
Table 1. Demographic and clinical characteristics of University of Virginia survey population

\begin{tabular}{|c|c|c|c|c|}
\hline & \multirow{2}{*}{$\begin{array}{l}\text { All admitted } \\
\text { ischemic } \\
\text { stroke cases } \\
(\mathrm{n}=154)\end{array}$} & \multicolumn{3}{|l|}{ Cases } \\
\hline & & $\begin{array}{l}\text { all } \\
\text { enrolled } \\
(\mathrm{n}=123)\end{array}$ & $\begin{array}{l}\text { with } \\
\text { control } \\
(\mathrm{n}=92)\end{array}$ & $\begin{array}{l}\text { without } \\
\text { control } \\
(\mathrm{n}=31)\end{array}$ \\
\hline \multicolumn{5}{|l|}{ Age, years } \\
\hline Mean & 66.6 & 67.3 & 66.1 & 70.6 \\
\hline Median & 67.5 & 69 & 67 & 72 \\
\hline Range & $27-92$ & $33-92$ & $33-85$ & $40-92$ \\
\hline Male, $\%$ & 57 & 57 & 61 & 45 \\
\hline \multicolumn{5}{|l|}{ Race, \% } \\
\hline White & 76 & 78 & 87 & 52 \\
\hline African-American & 23 & 20 & 13 & 42 \\
\hline Other $^{1}$ & 1 & 2 & 0 & 6 \\
\hline \multicolumn{5}{|l|}{ Risk factors, $\%$} \\
\hline Hypertension & NA & 71 & 71 & 71 \\
\hline Diabetes & NA & 31 & 29 & 35 \\
\hline Dyslipidemia & NA & 37 & 36 & 39 \\
\hline Atrial fibrillation & NA & 20 & 21 & 19 \\
\hline Coronary disease & NA & 31 & 32 & 29 \\
\hline \multicolumn{5}{|l|}{ Smoking status, \% } \\
\hline Current & NA & 21 & 21 & 23 \\
\hline Ex-smoker & NA & 29 & 30 & 26 \\
\hline Nonsmoker & NA & 47 & 49 & 42 \\
\hline \multicolumn{5}{|l|}{ Marital status, \% } \\
\hline Married & NA & 60 & 71 & 26 \\
\hline Widowed & NA & 24 & 16 & 48 \\
\hline Single & NA & 12 & 11 & 16 \\
\hline Divorced & NA & 4 & 2 & 10 \\
\hline \multicolumn{5}{|l|}{ Stroke subtype, \% } \\
\hline Large vessel & NA & 22 & 21 & 26 \\
\hline Small vessel & NA & 28 & 28 & 26 \\
\hline Cardioembolic & NA & 15 & 13 & 19 \\
\hline Cryptogenic & NA & 25 & 29 & 13 \\
\hline Multiple mechanisms & NA & 5 & 3 & 10 \\
\hline Other specified & NA & 2 & 1 & 6 \\
\hline Work-up incomplete & NA & 3 & 4 & 0 \\
\hline
\end{tabular}

NA $=$ Not available.

11 Asian-American and 1 white Hispanic-American.

\section{Statistical Methods}

Simple frequencies and means were calculated for the entire cohort and for those with and without available controls. Comparisons were made using a nonparametric $\chi^{2}$ test for categorical variables and one-way ANOVA for continuous variables. Alpha was set at 0.05. In addition, we used Bonferroni's methods for correcting for multiple comparisons in the University of Virginia dataset; a total of 13 statistical comparisons were made giving a corrected alpha of 0.004 . 
Table 2. Univariate comparison of demographic characteristics of cases and controls

\begin{tabular}{|c|c|c|c|c|c|}
\hline & \multirow[t]{2}{*}{$\begin{array}{l}\text { All controls } \\
(\mathrm{n}=129)\end{array}$} & \multicolumn{2}{|c|}{$\begin{array}{l}\text { Cases with control } \\
(\mathrm{n}=92)\end{array}$} & \multicolumn{2}{|c|}{$\begin{array}{l}\text { All cases } \\
(\mathrm{n}=123)\end{array}$} \\
\hline & & $\mathrm{n}$ & $\begin{array}{l}\text { p value vs. } \\
\text { controls }\end{array}$ & $\mathrm{n}$ & $\begin{array}{l}\mathrm{p} \text { value vs. } \\
\text { controls }\end{array}$ \\
\hline \multicolumn{6}{|l|}{ Age, years } \\
\hline Mean & 59.2 & 66.1 & 0.0001 & 67.3 & 0.000002 \\
\hline Median & 61 & & & 69 & \\
\hline Range & $24-85$ & $33-85$ & & $33-92$ & \\
\hline Male, $\%$ & 33 & 61 & 0.0002 & 57 & 0.0005 \\
\hline \multicolumn{6}{|l|}{ Race, \% } \\
\hline White & 85 & 87 & $0.49^{\mathrm{a}}$ & 78 & $0.08^{\mathrm{a}}$ \\
\hline African-American & 12 & 13 & & 20 & \\
\hline Other & 2 & 0 & & 2 & \\
\hline Unknown & 2 & 0 & & 0 & \\
\hline
\end{tabular}

\section{Results}

\section{Multisite Stroke Registry Results}

A total of 446 potential cases were identified during the surveillance period. Sixty-five percent (290/446) of the cases from all sites had a living spouse [Mayo Clinic, Jacksonville, Fla., 66\% (73/110); Mayo Clinic, Rochester, Minn., 68\% (128/188); Shands/University Hospital, Jacksonville, Fla., 64\% (16/25); University of Virginia Hospital, Charlottesville, Va., 60\% (73/123), $\mathrm{p}=0.45]$.

\section{University of Virginia Survey of Potential Probands}

From May 15, 2001 to December 31, 2001, 123 of the 154 stroke admissions (80\%) met enrollment criteria and were willing to answer the questionnaire. Three patients were admitted twice during the study interval but were only counted as single individuals. Reasons for exclusion included the following: unlikely to be able to provide informed consent for a genetics study $(n=17)$, discharged prior to approach $(n=9)$, admitted to another service $(n=$ $2)$, lost paperwork $(\mathrm{n}=2)$, and nonqualifying stroke $(\mathrm{n}=$ 1). Demographic, risk factor, and stroke subtype data are summarized in table 1 . A total of $51 \%(63 / 123)$ of cases reported a living, stroke-free spouse who would be willing to serve as a control. Only one such couple was not matched for race. Of the 73 cases who were married, $8 \%$ (6/73) did not believe their spouses would agree to participate and 5\% (4/73) reported that their spouse had a history of stroke. Forty-nine percent of cases (61/123) reported having an unrelated, stroke-free friend who would be will- ing to serve as a control. All but 3 of the 61 case-friend control pairs were matched for race. Twenty-seven percent $(33 / 123)$ reported both a living stroke-free spouse and a living stroke-free friend. Overall, 75\% (92/123) of stroke patients reported at least 1 unrelated, stroke-free individual who would likely be willing to serve as a control.

\section{Differences between Cases with and without Controls}

Table 1 shows the characteristics of cases with and without an identified control. Cases without an identified control were significantly more likely to be non-white $(48 \%)$ than were cases with a control $(13 \% ; p=0.00004)$. Marital status also differed between the two groups: those without controls were more frequently widowed, divorced, or single compared with those with an identified control ( 29 vs. $74 \% ; p=0.00009)$. Cases with an available spouse/friend control tended to be younger $(66.1 \pm 11.4$ vs. $70.6 \pm 12.7$ years; $p=0.07)$. The proportion of men was nonsignificantly higher between cases with $(61 \%)$ controls compared with those without controls $(45 \%, p=$ $0.13)$. The overall distributions of stroke subtypes did not differ $(p=0.15)$. This study was not powered to detect differences in risk factor profiles, but gross differences were not noted.

Sixty-six percent of those reporting a living and available spouse were men compared with $32 \%$ of those reporting no available spouse being men $(p=0.0002)$. By contrast, men were underrepresented among those reporting a stroke-free friend who might be willing to serve as a con- 
trol (43 vs. $58 \% ; p=0.09)$. More than $1 / 4$ of men $(29 \%)$ and women $(25 \%)$ reported both a spouse and a friend who could potentially serve as a control.

\section{Differences between Cases and Controls}

Table 2 compares cases and controls. Controls were significantly younger than all cases $(59.2 \pm 13.8$ years vs. $67.3 \pm 11.8$ years; $p=0.00003)$. There was a significantly greater proportion of females among controls $(67 \%)$ than among cases with $(39 \%, \mathrm{p}=0.0002)$ or without $(55 \%, \mathrm{p}=$ $0.0005)$ controls. There was a suggestion that the controls were more likely to be white ( 85 vs. $78 \% ; p=0.08$ ). If all cases agreed to participate, the cases would be $57 \%$ male (70/123), 78\% white (96/123), and have a median age of 69 years. If all identified potential controls agreed to participate, the control group would be $33 \%$ (43/129) male, $85 \%$ white $(110 / 129)$ and have a median age of 61 years.

\section{Discussion}

Our study shows that approximately two thirds of adults with recent ischemic stroke reported having a living spouse. The availability of spouse controls was consistent across sites; however, it may differ in populations outside the USA. In a recent study of 727 patients seen at a single cerebrovascular clinic in London, UK, there were $222(30.5 \%)$ available stroke-free spouses; but the authors did not define what constituted an available spouse in their study [14]. Thus, the difference in rates of spouse controls may be due to a bias in ascertainment.

At the University of Virginia site, three quarters of ischemic stroke cases reported having an available spouse or unrelated friend who would likely serve as a control. As would be anticipated, cases were more likely to have living spouses available for controls if they were male or younger in age, making a greater proportion of controls female and younger. Care must be taken to avoid imbalances between cases and controls with regard to basic demographic characteristics such as age and sex.

The University of Virginia survey inquired about patients' willingness to participate in a hypothetical genetics study. The number of controls stating a willingness to participate in a hypothetical study likely exceeds the number of controls who would provide informed consent for an actual nontherapeutic study. Complex factors influence rates of refusal to participate in medical research. Refusal of elderly subjects to participate in observational studies has been shown to be influenced by the functional [15] and cognitive status [16]. Even the manner with which informed consent is obtained can affect refusal rates. The Eastern Cooperative Oncology Group, for example, found that rates of refusal to bank biological samples for future research were lower when more detailed information was included in the informed consent form [17].

\section{Case-Control Design}

Although genome-wide scans for susceptibility genes will become easier as data accrue from the human genome project, the case-control method remains a powerful tool for genetic investigation $[8,18]$. This is especially true for diseases like cerebrovascular disease where multiple genes, rather than one particular gene, determine the risk. Case-control studies are most useful to detect the impact of common alleles that confer a modest effect [19]; however, confounding due to gene-environment interactions remains a vulnerability [20].

The possibility of introducing an asymptotic bias secondary to ethnic stratification represents a limitation in the case-control study design. Imbalances in the ethnic make-up between cases and controls may lead to spurious results due to differences in the frequency of polymorphic regions of the genome [21-23]. Real associations between ethnicity and disease may lead to an artifactual association of that disease with benign polymorphisms [24, 25]. Overcoming ethnic stratification can be achieved through extremely narrow sampling, but this strategy greatly sacrifices efficiency [26]. Nevertheless, ethnic stratification may be quantifiable and smaller than previously thought [27]. Case-related control and combined case-control pedigree designs provide alternative strategies that readily control for ethnic differences; however, these methods may be less efficient for common low penetrant polymorphisms and curtail both power and generalizability [2830].

\section{Control Selection}

The use of spousal controls has clear advantages both for convenience and for controlling for adult environmental exposure [12]. Racial backgrounds are often matched in both spouses and friends as can be seen from our population. Friends also provide a convenient pool of potential controls with similar lifestyle characteristics [31]. However, some have criticized the use of friend controls because of a tendency to oversample sociable individuals $[32,33]$. Genetic traits may not be related to sociability, making this pool of controls perhaps more acceptable in genetic association studies such as our planned study [31, 34]. In genetic studies, these particular issues of bias and issues of overmatching are of less significance because 
exposure to particular genes is not likely related to social characteristics $[12,31]$. We therefore do not believe this to be a significant limitation in our study.

Using a combination of spousal and friend controls is appealing and may allow for corrections of anticipated imbalances between cases and potential controls. In our sample, given that males were more likely to have male friends, it would be possible to correct for the difference in sex between cases and spousal controls by supplementing with friend controls. As the ages of spousal controls more closely approximated the cases' age than the friends' age, using friend controls is less likely to be helpful in correcting for imbalances in age.

In an effort to address potential imbalances in demographic characteristics identified in our survey of potential cases, we propose adapting methodologies developed in behavioral case-control studies that apply random selection to a convenience sample. In that design, cases provide a list of potential friend controls from which researchers randomly chose a single control to minimize selection bias [35]. We propose using a similar strategy whereby cases provide a list of potential controls that are added to a pool allowing selection of the most appropriately matched control for each case.

Although spouse and friend controls can be used as controls in genetic studies, the availability of such controls is limited by willingness of cases to identify potential controls, and the controls' willingness to participate. Although in some realms of research, case identification of controls is limited [34], in our population this was not the case. Our study did not, however, address the actual willingness of identified potential controls to participate. We will systematically collect data regarding recruitment of spousal and friend controls as part of the planned multisite ischemic stroke genetic study, which will allow further investigation of the impact of actual willingness to serve as a control on the characteristics of the pool of potential control subjects.

\section{Conclusions}

Genetic investigations in cerebrovascular disease are increasing as the tools available to researchers expand. Risk stratification based on genetic profiles is expected to increase [36]. Genetic information may also expand or reform treatment modalities [37]. Recognition of the genes that play a role in cerebrovascular risk is inherent to this process. The current study both characterized the likely pool of spouse and unrelated friend controls and identified particular features of potential controls, including sex, age, and race/ethnicity, which require careful attention in designing and conducting case-control stroke genetic studies.

\section{Acknowledgments}

The authors wish to thank the participants for their willingness to contribute to this work.

For this study, Dr. Worrall was supported in part by a Clinical Research Training Fellowship Grant from the American Academy of Neurology. Drs. Brott, Robert Brown, Silliman, Worrall, and Meschia are supported by the National Institute of Neurological Disorders and Stroke of the National Institutes of Health (Grant No. NS39987).

\section{References}

1 Kiely DK, Wolf PA, Cupples LA, Beiser AS, Myers RH: Familial aggregation of stroke. The Framingham Study. Stroke 1993;24:13661371

2 Liao D, Myers R, Hunt S, Shahar E, Paton C, Burke G, Province M, Heiss G: Familial history of stroke and risk. The Family Heart Study. Stroke 1997;28:1908-1912.

3 Caicoya M, Corrales C, Rodriguez T: Family history and stroke: A community case-control study in Asturias, Spain. J Epidemiol Biostat 1999;4:313-320.

4 Jousilahti P, Rastenyte D, Tuomilehto J, Sarti C, Vartiainen E: Parental history of cardiovascular disease and risk of stroke. A prospective follow-up of 14,371 middle-aged men and women in Finland. Stroke 1997;28:13611366 .
5 Bak S, Gaist D, Sindrup SH, Skytthe A, Christensen K: Genetic liability in stroke: A longterm follow-up study of Danish twins. Stroke 2002;33:769-374.

6 Wannamethee SG, Shaper AG, Ebrahim S: History of parental death from stroke or heart trouble and the risk of stroke in middle-aged men. Stroke 1996;27:1492-1498.

7 Meschia JF, Brown RD Jr, Brott TG, Chukwudelunzu FE, Hardy J, Rich SS: The Siblings with Ischemic Stroke Study (SWISS) Protocol. BMC Med Genet 2002;3:1.

8 Clayton D, McKeigue PM: Epidemiological methods for studying genes and environmental factors in complex diseases. Lancet 2001;358: 1356-1360.
9 Fingerlin TE, Erdos MR, Watanabe RM, Wiles KR, Stringham HM, Mohlke KL, Silander K, Valle TT, Buchanan TA, Tuomilehto J, Bergman RN, Boehnke M, Collins FS: Variation in three single nucleotide polymorphisms in the calpain- 10 gene not associated with type 2 diabetes in a large Finnish cohort. Diabetes 2002; 51:1644-1648.

10 Elbein SC, Wegner K, Miles C, Yu L, Eisenbarth G: The role of late-onset autoimmune diabetes in white familial NIDDM pedigrees. Diabetes Care 1997;20:1248-1251.

11 O'Dea DF, Murphy SW, Hefferton D, Parfrey PS: Higher risk for renal failure in first-degree relatives of white patients with end-stage renal disease: A population-based study. Am J Kidney Dis 1998;32:794-801. 
12 Wacholder S, Silverman DT, McLaughlin JK, Mandel JS: Selection of controls in case-control studies. 2. Types of controls. Am J Epidemiol 1992;135:1029-1041.

13 Adams HP Jr, Bendixen BH, Kappelle LJ, Biller J, Love BB, Gordon DL, Marsh EE 3rd Classification of subtype of acute ischemic stroke. Definitions for use in a multicenter clinical trial. TOAST. Trial of Org 10172 in Acute Stroke Treatment. Stroke 1993;24:35-41.

14 Hassan A, Sham PC, Markus HS: Planning genetic studies in human stroke: Sample size estimates based on family history data. Neurology 2002;58:1483-1488.

15 Tennstedt SL, Dettling U, McKinlay JB: Refusal rates in a longitudinal study of older people: Implications for field methods. J Gerontol 1992;47:S313-S318.

16 Jacomb PA, Jorm AF, Korten AE, Christensen $\mathrm{H}$, Henderson AS: Predictors of refusal to participate: A longitudinal health survey of the elderly in Australia. BMC Public Health 2002; $2: 4$

17 Malone T, Catalano PJ, O'Dwyer PJ, Giantonio $\mathrm{B}$ : High rate of consent to bank biologic samples for future research: The Eastern Cooperative Oncology Group experience. J Nat Cancer Inst 2002;94:769-771.

18 Brennan P: Design and analysis in case-control studies addressing genetic susceptibility. IARC Sci Publ 1999;148:123-132.

19 Whittemore AS, Nelson LM: Study design in genetic epidemiology: Theoretical and practical considerations. J Natl Cancer Inst Monogr 1999;26:61-69.

20 Garcia-Closas M, Thompson WD, Robins JM Differential misclassification and the assessment of gene-environment interactions in casecontrol studies. Am J Epidemiol 1998;147: 426-433.
21 Blum K, Noble EP, Sheridan PJ, Montgomery A, Ritchie T, Jagadeeswaran P, Nogami H, Briggs A, Cohn JB: Allelic association of human dopamine $\mathrm{D}_{2}$ receptor gene in alcoholism. JAMA 1990;263:2055-2060.

22 Gelernter J, Goldman D, Risch N: The A1 allele at the $\mathrm{D}_{2}$ dopamine receptor gene and alcoholism. A reappraisal. JAMA 1993;269: 1673-1677.

23 Gutensohn N, Li FP, Johnson RE, Cole P: Hodgkin's disease, tonsillectomy and family size. N Engl J Med 1975;292:22-25.

24 Caporaso N, Rothman N, Wacholder S: Casecontrol studies of common alleles and environmental factors. J Natl Cancer Inst Monogr 1999;26:25-30.

25 Thomas DC: Design of gene characterization studies: An overview. J Natl Cancer Inst Monogr 1999;26:17-23.

26 Witte JS, Gauderman WJ, Thomas DC: Asymptotic bias and efficiency in case-control studies of candidate genes and gene-environment interactions: Basic family designs. Am J Epidemiol 1999;149:693-705.

27 Wacholder S, Rothman N, Caporaso N: Population stratification in epidemiologic studies of common genetic variants and cancer: Quantification of bias. J Natl Cancer Inst 2000;92: 1151-1158.

28 Hsu L, Zhao LP, Aragaki C: A note on a conditional-likelihood approach for family-based association studies of candidate genes. Hum Hered 2000;50:194-200.
29 Hopper JL, Chenevix-Trench G, Jolley DJ, Dite GS, Henkins MA, Venter DJ, McCredie $\mathrm{MR}$, Giles GG: Design and analysis issues in a population-based, case-control-family study of the genetic epidemiology of breast cancer and the Co-operative Family Registry for Breast Cancer Studies (CFRBCS). J Natl Cancer Inst Monogr 1999;26:95-100.

30 Hopper JL: The epidemiology of genetic epidemiology. Acta Genet Med Gemellol (Roma) 1992;41:261-273.

31 Flanders WD, Austin H: Possibility of selection bias in matched case-control studies using friend controls. Am J Epidemiol 1986;124: 150-153.

32 Robins J, Pike M: The validity of case-control studies with nonrandom selection of controls. Epidemiology 1990;1:273-284.

33 Austin H, Flanders WD, Rothman KJ: Bias arising in case-control studies from selection of controls from overlapping groups. Int J Epidemiol 1989;18:713-716.

34 Shaw GL, Tucker MA, Kase RG, Hoover RN: Problems ascertaining friend controls in a casecontrol study of lung cancer. Am J Epidemiol 1991;133:63-66.

35 Thompson WD: Nonrandom yet unbiased. Epidemiology 1990;1:262-265.

36 Winkelmann BR, Marz W, Boehm BO, Zotz R, Hager J, Hellstern P, Senges J: Rationale and design of the LURIC study - a resource for functional genomics, pharmacogenomics and long-term prognosis of cardiovascular disease. Pharmacogenomics 2001;2:S1-S73.

37 Psaty BM, Smith NL, Heckbert SR, Vos HL, Lemaitre RN, Reiner AP, Siscovick DS, Bis J, Lumley T, Longstreth WT Jr, Rosendaal FR: Diuretic therapy, the alpha-adducin gene variant, and the risk of myocardial infarction or stroke in persons with treated hypertension. JAMA 2002;287:1680-1689. 